\title{
Political Economy of the EU Competition Policy
}

\author{
AB Rekabet Politikasinin Ekonomipolitiği
}

\author{
Assoc. Dr. Hakan Cavlak ${ }^{1}$
}

Başvuru Tarihi: 26.04.2018

Kabul Tarihi: 10.04.2019

\begin{abstract}
This article explores the effect of European Competition Policy as the means of the EU in global political economy. Competition policy can be identified as an important tool for the $E U$ in its external relations. It both helps to increase the chance of domestic producers to reach foreign markets and regulates foreign firms and their products within the single market. Thus, the competition policy carries the EU up in the international political economy and helps the EU to be recognized as an international actor. Within the Single Market the EU exercise an exclusive power through competition policy. Externally, competition policy is one of the most effective international powers that EU exercises as it has the ability to regulate international mergers or even initiate cartel investigations. Alongside assessing the competition policy, this study focuses especially on some selected international cases of which the EU is a party through its competition law. It is argued, in this article, that the international power of the EU stemmed considerably from its competition policy which is integral in global political economy.
\end{abstract}

Keywords: EU External Policy, International Relations, Liberalization, Globalization, International Economics

\section{Öz}

Bu çalışma ile Avrupa Birliğinin Rekabet Politikasının küresel ekonomi politiği nasıl etkilediği keşfedilmeye çalışılmıştır. Rekabet politikası AB'nin dış ilişkilerde kullanabildiği önemli bir araç olarak nitelendirilebilir. $A B$, bununla hem yerli üreticilerin yabancı pazarlara ulaşma şansını arttırmakta hem de yabancı firmaları ve onların ürünlerini tek pazarda düzenleyebilmektedir. Böylece, rekabet politikası AB'yi uluslararası ekonomi politiğe taşımakta ve AB'nin uluslararası bir aktör olarak tanınmasına yardımcı olmaktadır. Tek pazarda birlik içi rekabet konusunda $A B$ münhasır yetkiye sahiptir. Dışarıda ise rekabet politikası AB'nin en etkin kullanabildiği dış politika aracıdır, bununla AB uluslararası şirket birleşmeleri düzenleyebilir hatta soruşturma dahi gerçekleştirebilir. Bu çalışma, rekabet politikasını incelemenin yanında, AB'nin rekabet hukuku yoluyla taraf olduğu seçilmiş bazı davalara da odaklanmaktadır. Bu çalışmanın temel iddiası, AB'nin uluslararası gücü ciddi bir oranda rekabet politikasına dayanmaktadır ve bu da küresel ekonomi politiğin çok önemli bir unsurudur.

Anahtar Kelimeler: AB Dış Politikası, Uluslararası İlişkiler, Liberalizasyon, Küreselleşme, Uluslararası Ekonomi

${ }^{1}$ Tekirdağ Namik Kemal University Faculty of Economics and Administrative Sciences, hakancavlak@gmail.com, ORCID: 0000-0003-1119-9900 


\section{Introduction}

The European Union (EU) is the largest economic and trading bloc of the world. The Gross Domestic Product (GDP) of the EU is around 19 Trillion \$. The market share of the EU in world is almost $18 \%$. The EU operates in three different levels of market: the first level as the domestic market, which is the market of the member states, the second as the single market which is the integrated intra EU market and the third as the international or global market. The EU as a polity has influence on all three levels of markets. One of the most efficient tools of the EU in manipulating those markets is the Competition Policy. In this study, the effect of the EU through its Competition Policy on international economics would be assessed from a political economy (PE) perspective. In order to clarify the viewpoint, the contentious issue of political economy first would be elaborated.

The interaction of state and market produce political economy (Gilpin, 1987, p. 8). In other words without state or market there is no political economy. In order to prevent any ambiguity in advance, in this study the EU is considered not exactly as a state but with its well-integrated single market and harmoniously functioning economics it is deliberated as a state-like political entity. Although some analysts, for mainly research reasons, focus only on economic factors such as price mechanisms and market forces, or focus only on political factors and excluding market forces and considering the states as the sole resource allocator, to explain the functioning of the world's economic and political system. These two pure forms of world never exists however, the effect of market or states changes due to change in the time and different circumstances.

Apart from the vague definition of political economy, there is hardly an academic consensus on what the political economy is, what it is dealt with, what its methodology is etc. For instance, Adam Smith and classical economist used as the science of economics of today. Recently, it is defined as a methodology in which the rational actor model of economics is used to explain all human behavior (Cohn, 2012, p. 9). Some others simply define it as applying of a specific economic theory to describe a social action (Cohn, 2012, p. 9). Still some other scholars explain political economy as a set of questions generated through the interactions between economic and political activities (Cohn, 2012, p. 10). Although, most scholars consider political economy as a state - market interaction political economy may also deal with the interaction between the state and Multinational Corporation a major non-state actor (Cohn, 2012, p. 11). Whether it focuses on state market or state Multinational Corporations interactions, the political economy is an interdisciplinary approach and borrows perspectives, theories and methodologies from political science, economics, sociology, history, geography etc. From time to time it may be criticized as for being too economist i.e. emphasizing economics too much compared to politics or for being too politicist i.e. focusing on politics and overseeing economics. In either way political economy seems an efficient way to deal real cases both have influence on politics and economics.

The Competition Policy of the EU is a politically driven tool which has direct effect on domestic markets of the member states, single market and global market. Thus, any case related to Competition Policy suits to be researched from a viewpoint of political economy. 
The competition policy of the EU consists of three major objectives. The first one is similar to any other competition authority: ensuring that competition to be the driving force of the economy and pursuing of open market through anti-trust regulations. The second, preservation of Single Market, this is unique to the European Union. Although it has been paid less attention in the treaties, the third objective has gained considerable importance recently that is bilateral and multilateral international cooperation in economic activities as the consequence of globalization (Damro, 2001, p. 209).

The force of competition in the Single Market and in the international economy obliged the EU to increase the efficiency of the competition policy. An extraterritorially use of competition policy would mainly be beneficial for the domestic producers by enhancing their access to foreign markets (De Bièvre \& Eckhardt, 2010). So the competition policy can be identified as an important tool for the EU in its external relations by increasing the chance of domestic producers to reach foreign markets. Thus, the competition policy carries the EU up in the international political economy and helps the EU to be recognized as an international actor. Therefore, the EU actively participates in international competition policy negotiations as leading advocate of global competition coordination. Within the Single Market the EU exercise an exclusive power through competition policy. Externally, competition policy is one of the most effective international powers that EU exercises as it has the ability to regulate international mergers or even initiate cartel investigations. However, the use of competition policy power in international arena may cause some disagreements with trading partners and the EU which can produce tensions. So, it can be argued that the international power of the EU stemmed from competition policy is integral in global economic order.

\section{Competition in the EU}

Since the signing of the Treaty of Rome the EU's competition policy has been one of the most essential parts of EU policies. Rome Treaty formed a system in which fair competition in the common market is ensured. The main objective of such a system was to institute some welldeveloped and efficient competition rules for guaranteeing proper functioning of European market and providing a consumer friendly market. Competition policy can be defined basically as setting and applying rules to ensure firms compete fairly which encourages companies to be more efficient and provides more opportunities for consumers (Jones \& Sufrin, 2011, p. 98). This helps decrease in prices and increase in quality. Moreover, competition within the EU would provide EU firms a stronger position in global markets. Usually, if a break in competition rules occurs in one country, it is handled by the national competition authorities. However, as the single market deepens and grows, together with the effects of globalization, the impact of illegal actions, such as abusing a dominant position, are typically felt EU wide even beyond. In such cases the European Commission has the powers of investigation, taking binding decisions and imposes penal charges (Jones \& Sufrin, 2011, p. 102). The Commission generally acts together with the national competition authorities of the member states of the EU in enforcing competition rules.

The EU competition policy is an integral part of the single market. The basic focus areas of the competition policy are struggling against all sorts of cartels, preventing dominant companies 
to abuse their position, scrutinizing of planned mergers and monitoring the state aids that may distort competition (Jones \& Sufrin, 2011, p. 99). These basic duties and authority of the EU comes directly from the founding treaties. These rules are designed in the Treaty on the Functioning of the EU (TFEU) as follows:

- "Companies cannot agree to fix prices or divide up markets amongst themselves (Article 101 TFEU);

- Companies cannot abuse a dominant position in a particular market to squeeze out smaller competitors (Article 102 TFEU);

- Companies are not allowed to merge if that would put them in a position to control the market. Larger companies that do a lot of business in the EU cannot merge without prior approval from the European Commission - even if they are based outside the EU (the merger regulation).

- EU rules also cover government assistance to businesses (state aid), which is monitored by the Commission (Article 107 TFEU). The following, for example, are forbidden unless they comply with certain criteria: loans and grants; tax breaks; goods and services provided at preferential rates; government guarantees which enhance the credit rating of a company compared to its competitors. Also, no state aid in any form may be given to ailing businesses that have no hope of becoming economically viable." (European Commission Directorate-General for Communication, 2014, p. 4)

The competition policy, as it can be observed above, has four basic branches. These are: Antitrust, State aid, Mergers, Liberalization.

In terms of competition policy, antitrust means avoiding or controlling trusts or other monopolies. The main aim of antitrust actions is to promote competition in market. One of the renowned means of forming trusts or monopolies is to make anticompetitive agreements, which refer to all agreements reducing competition regardless of the parties intended to restrict competition such as cartels where companies decide to evade competing with each other, or settle the prices at which their products will be sold. However, this does not mean restricting any kind of agreements among companies. For instance, agreements to collaborate in creating a technical standard for the market are allowed by the Commission. Moreover, Research and development agreements and technology transfer agreements usually tolerated by the Commission as those kinds of agreements often serve to the interests of the consumers and they are too expensive to be afforded by one company (European Commission Directorate-General for Communication, 2014, p. 8). Furthermore, cooperation among the small businesses may also be tolerated by the Commission if they increase their competitiveness against larger companies. TFEU bans anticompetitive agreements with the article 101. The antitrust rules on anticompetitive agreements can be found in various regulations some of which deal with particular type of conduct and others deal with specific sectors (European Commission Directorate-General for Communication, 2014, p. 9). The Commission's powers to investigate businesses are also defined in these regulations. 
Abuse of a dominant position is an important component of the European Competition Policy. Competition can be restricted by a company if it is strong enough to control a particular market. Every company that holds a dominant position cannot be directly considered anticompetitive; however, if the company uses its position to restrict or remove competition then an abusive behavior is on place. Abuse of dominant position is prohibited by Article 102 of the TFEU. An abuse of dominant position is usually revealed if a major player in a particular market pushes its competitors out of the market which results in removing competition in the given market that reduce choice and cause higher prices for consumers (European Commission Directorate-General for Communication, 2014, p. 11). Moreover, abuse of dominant behavior can be traced in conducts as, for example, asking irrationally high prices, charging extremely low prices to harm or eliminate its competitors from the market, making compulsory to buy a product to use another related product for excluding alternatives for both types products, refusing to deal with certain customers or selling one product only on the condition of selling another product (Whish \& Bailey, 2015, p. 729).

The Commission has the right to investigate anticompetitive conducts if it suspects or a complaint is made. The powers of the Commission in investigating are encompassing entering any company premises, land or mean of transport; assess the business records, obtain copies from those records; seal companies premises, books or records within the period of investigation; and the Commission can ask explanations from representatives or employees of the firm about the facts or documents relating to the case and record the answers.

State Aids are one of the most important issues that the Commission deals with concerning competition. The competition could be damaged by national governments' supports to local industries or businesses through public money. The Article 107 of the TFEU prohibits this kind of policies. The Article 108 authorizes the Commission to prevent such actions. The national governments are only allowed to support local businesses if it is clearly in the wider public interest. The Commission judges the state aids through several criteria whether they infringe the competition rules or not. Firstly, the Commission hears if any state aid is given, for example, in the form of grants, interest or tax relief, guarantees etc. The most decisive condition that mobilizes the Commission is if the aid likely to has impact on trade among the EU countries. Then the Commission evaluates if the measures taken are selective namely, do they provide an advantage to a specific company or sector in a specific region. Finally, the Commission analyzes the situation if it distorts competition. On these grounds, the Commission, can interfere and has the power to prohibit such actions (Cini \& McGowan, 1998, p. 137).

Mergers are also one of the main areas concerning competition related issues. The Merger Regulation, which contains the main rules to evaluate concentrations, authorizes the European Commission to ban acquisitions and mergers that may considerably reduce competition. The mergers or acquisitions may increase efficiency through developing new products, reducing production or distribution costs that make the market more competitive and consumers may benefit from it. However, some mergers may reduce competition through 
consolidating a major company that potentially detriment consumers by higher prices, reduced choices or less innovation. Thus, if companies that operate cross-border are planning to merge they have to first ask permission from the Commission and provide any information it needs to analyze and make a decision (Motta, 2004, p. 36). Competition authorities have to be sure that joining of forces of the two or more businesses will not result in creating a dominant position in the market.

The rules concerning competition set by the EU and monitored by the Commission have some serious consequences. The Commission examines if companies infringe or will infringe the rules of competition to pursue a competitive market in the EU. So, the Commission has the power of banning a certain behavior, ask for corrective action or impose a fine according the particular situation. In other words, the Commission either prevents or punishes competition violations. The EU competition rules are directly applicable in all EU members. The national competition authorities can choice between their national rules and EU competition laws. The Commission can act only if an anticompetitive behavior has an impact on Single Market. The Commission is quite powerful on competition issues, the decisions of the Commission are binding on both businesses and national authorities which infringes EU competition laws; however, the decisions can be appealed to the General Court of the EU and can be furthered to the Court of Justice.

The solid results on good of consumers, for example, about prohibiting cartels were estimated around $€ 4.89$ to 5.66 billion in 2013 (European Commission Directorate-General for Communication, 2014). The money received as fines do not increase the budget of the EU but decrease the amount of member countries' contribution to the EU budget. The famous and big scaled cases that the Commission pursued in previous years about anticompetitive conducts benefited the European consumer. One of the most famous and great cases of the EU concerning competition has been against the US software giant, Microsoft. Microsoft has been fined by the Commission on the grounds of bundling several kinds of software in a single set. The decision called that Microsoft had been uncompetitive by decreasing choice of consumers, setting prices deliberately high and becloud innovation in the sector of software (European Commission, 2015a). In 2012, again an important case had been held against Asian television and computer monitor producers by the EU and they are fined $€ 1.47$ billion as they formed a two decade long cartel. It had been found out that those particular producers had agreed on prices and exchanging important information on large screens and computer monitors, which had direct impact on consumers of the EU, as most of those type of products are imported from Asia. An important merger case had been the case of Ryanair. In 2006 and 2012, Ryanair asked permission from the Commission to take over Irish national carrier Aer Lingus. The Commission analyzed the potential influence of such an acquisition on competition and consumers, especially concerned about the 14 million passengers flying from or to Ireland every year. The investigation resulted as this merger would create a monopoly or a dominant position for one company on many routes to or from Ireland, thus, gives the chance to the company to manipulate prices and quality (European Commission, 2013). 


\section{Implementation of the Competition Policy at the EU Level}

The significance of competition had been emphasized by the founding members of the EU throughout the establishment of the European Communities. Competition is crucial for the liberal economic system as well as for the single market. Thus, a competition policy has been formed at the community level. Monitoring competition related issues would no longer in the grip of national authorities. The main objective of the UE competition policy has been to ensure an operating healthy economy. Therefore, competition policy has been founded as a classic common policy, even, article 3 of the EC Treaty stressed that "a system guaranteeing undistorted competition on the internal market should be established." Article 81 to 89 of the EC Treaty regulates Competition policy. The Commission, which guards competition in the $\mathrm{EU}$, has the central role in the implementation of the competition policy. The Council regulations, Commission regulations, general communications and individual decisions are the main tools applied in operating competition policy. The European Commission and the national authorities work in accordance to monitor anticompetitive conducts.

The European Competition Network (ECN) is the important player of the newly developed coordination system. Advisory Committee on Restrictive Practices and Dominant Positions (ACRPDP), which is composed of representatives of national competition authorities, is an important element. The Commission consults to the committee (European Commission, 2015b). On a complaint or by its own initiative, if the Commission detects a breach of article either 81 or 82 of the EC Treaty, it has the authority to ask those parties to finish such breaches. Moreover, the Commission has the right to impose fines or other punishments to pull the companies in line with the EU's competition policy (Cini \& McGowan, 1998, p. 40). To charging a fine or not and the amount of the fine is depending on the degree of breach, its length the size of companies. The actions of the Commission are monitored legally by the Court of Justice and politically by the European Parliament (Cini \& McGowan, 1998, p. 42). The national competition authorities have to work in coordination with the Commission and the national authorities of the other member states (Cini \& McGowan, 1998, p. 51). Information exchange is crucial for evaluation of cases breaching article 81 or 82 of the EC Treaty. The Commission is entitled throughout the EU to ask such information to be delivered. In cases concerning competition, competence of member states and the EU are autonomous and parallel. However, the EU law has supremacy over national laws. If there is a conflict among EU law and national authorities, national authorities have to apply EU competition law. The member states have not a right to counter Commission's decision. National courts either apply the community law or if it is necessary, refer the case to the Court of Justice for a preliminary ruling.

A market can be monopolized by two ways either by agreement or by concentration. When a concentration is beyond to certain limits, it becomes dangerous as holding a dominant position and having the ability to abuse it (Cini \& McGowan, 1998, p. 61). Thus, one of the most important tasks of the European Commission according to competition law is to restrict any monopolization in the single market, which reduces competition. According to article 81 of the EC Treaty: "all agreements between undertakings, decisions by associations of undertakings and concerted practices which may affect trade between Member States and which 
have as their object or effect the prevention, restriction or distortion of competition within the common market". Thus, the Treaty prohibits all kind of agreements, either vertical or horizontal, which distort competition in the single market. Any firms operating in the single market are subject the competition provisions of the EU law regardless of being registered in the EU or not. Of course, the EU prohibits not all agreements. There are also agreements either having very minor effect on competition or even promotes competition, these types of agreements are not proceeded by the Commission.

Abusing dominant position within the EU, which can distort fair competition, is also prohibited by the EU Treaty Article 82 . Actually, the dominant position itself has not been restricted, only it interferes with the trade between Member States. The national authorities usually forbid such conduct, as well. The abuse of dominant position usually occurs where an undertaking strengthens its position through concentration or elimination of its rivals and thus, eliminates fair competition (Whish \& Bailey, 2015, p. 721). Although they are an integral part of EU competition policy, there are no measures mentioned in the Treaty about controlling concentrations or mergers. This area is designed by a regulation (Regulation 4064/89EEC) which is amended in 1997 by (Regulation/1310/97/EC). According to the Regulation undertakings offering a concentration or merger that have EU dimension must inform the Commission before the merger happens. This condition is valid for mergers covering at least 2.5 billion Euro global turnovers and turnover in at least three members more than 100 Million Euro each (European Commission, 2015b).

The EU also practices competition policy concerning member states, since they, directly or indirectly, may distort competition in the single market, as well. Numerous aids given by the states may restrict competition in the Single Market in favor of the subsidized party. The Article 87 of the EU Treaty clearly states that "any aid granted by a Member State or through State resources in any form whatsoever which distorts or threatens to distort competition by favoring certain undertakings or the production of certain goods shall, insofar as it affects trade between Member States, be incompatible with the common market". However, this does not mean that state aid is completely restricted by the EU law. If State aids have the objective of serving economic and social interests of the Union and do not restrict competition. The exemptions from the prohibition on state aids are as follows: aids supporting small and medium-sized enterprises, research and development, environmental protection and increased employment, as well as regional aid in certain regions approved by the Commission (Cini \& McGowan, 1998, p. 65).

Moreover, the Commission acts as the only authority in the field of international competition issues concerning the EU area. For instance, the EU signed a bilateral agreement with the USA in 1991 about competition (Whish \& Bailey, 2015, p. 521). According to that agreement, if enforcement of giving information when competition activities have effect the significant interests of the other party; sharing information; taking measures against anticompetitive actions which are consistent with objectives of the other party; consultation. This agreement also stresses the cases happening in one party but having negative effect on the other one. In 
the following section recent cases concerning competition will be displayed in order to analyze the effect of the competition law on real economy.

\section{Recent Events Concerning EU Competition Policy}

One of the most recent competition cases concerning global economy having been the tax treatment of Luxembourg for McDonald's. An investigation has been opened by the Commission into tax treatment of McDonald's by Luxembourg. It has preliminarily stated that tax ruling of Luxembourg to McDonald's provides an advantageous position against the EU state aid rules. Following claims in the media, the European Commission asked for information on tax rulings made by Luxembourg for McDonald's in 2014 (European Commission, 2015c). According to the Commission's evaluation Luxembourg granted two tax rulings to McDonald's. In the first tax ruling, in 2009, it has been declared that European Franchising of McDonald's was not due to pay corporate tax since its profits would be subject to taxation in the United States (US). Since 2009 McDonald's has not paid corporate tax in Luxembourg or US on its profits. According Luxembourg - US double taxation Treaty, the profits of McDonald's would be transferred to the US and will be subject to taxation in the USA. However, against the first ruling the profits of McDonald's have not been subject to taxation in Luxembourg neither in the US. McDonald's requested a second ruling stating that Luxembourg should nevertheless exempt the profits not taxed in the US from taxation in Luxembourg (European Commission, 2015c). So, according to this ruling the European Franchise of McDonald's is not subject to taxation in Luxembourg regardless of it is subject to taxation in the US.

The Commission currently investigates if this situation infringes the EU state aid rules and provides a favorable tax treatment to McDonald's compared other companies operating in similar businesses. The article 107 of the TFEU "state aid which affects trade between Member States and threatens to distort competition by favoring certain undertakings is in principle incompatible with the EU Single Market". Tax rulings similar to this one are not categorically ruled out by the EU if it applies to all companies operating in similar sectors. However, tax rulings providing selective advantage to a certain company which can seriously distort competition in the Single Market and breach EU Competition Law are considered infringement against the EU law.

The Gazprom case is also internationally significant case concerning EU competition policy. The European Commission in April indicted Russia's state - owned energy firm Gazprom about breaching the rules of single market. According, the preliminary view of the Commission "Gazprom is breaking EU antitrust rules by pursuing an overall strategy to partition Central and Eastern European gas markets, for example by reducing its customers' ability to resell the gas cross-border" (European Commission, 2015d). This policy of the Gazprom resulted in charging unfair prices in, especially Eastern and Central European, EU countries. Gazprom is also holding a dominant position in energy market and abuses this position by asking irrelevant commitments from customers concerning the infrastructure of gas transferring. 
The vitality of natural gas supply is underlined and Gazprom is criticized by the EU competition policy Commissioner Margrethe Vestager as:

"Gas is an essential commodity in our daily life: it heats our homes, we use it for cooking and to produce electricity. Maintaining fair competition in European gas markets is therefore of utmost importance. All companies that operate in the European market - no matter if they are European or not - have to play by our EU rules. I am concerned that Gazprom is breaking EU antitrust rules by abusing its dominant position on EU gas markets. We find that it may have built artificial barriers preventing gas from flowing from certain Central Eastern European countries to others, hindering cross-border competition. Keeping national gas markets separate also allowed Gazprom to charge prices that we at this stage consider to be unfair. If our concerns were confirmed, Gazprom would have to face the legal consequences of its behavior." (European Commission, 2015d)

Gazprom holds the dominant position as gas supplier in all Eastern and Central European members of the EU, with market shares from 50\% to 100\% (European Commission, 2015c). The article 102 of TFEU strictly forbids abusing dominant position that affects the trade between EU member states. As mentioned in previous section implementation of this rule is identified in Council Regulation (EC) No: 1/2003, the so called “Antirust Regulation”. This regulation gives powers to both the Commission and the national competition authorities.

Article 102 TFEU prohibits the abuse of a dominant market position, which may affect trade between Member States. Implementation of this provision is defined in the Antitrust Regulation (Council Regulation (EC) No 1/2003) (EU, 2003), which can be applied by the Commission and by the national competition authorities of EU Member States. According the authority given the Commission by the Antitrust Regulation, the procedure in such cases is initiated by a Statement of Objections towards suspected firms. The Commission informs by this objection the related parties and these parties can reply in the objections raised against them (European Commission, 2015c). The decision of the Commission is only made after all the rights of defense are exercised. There is not a legal deadline for the Commission finalizing antitrust investigations; the duration depends on the complexity of the case.

One of the competition cases which attract global attention is the investigation made against Google. The Commission has made a Statement of Objections alleging Google of treating more favorably, in its general search results pages, Google's own services of comparison "Google Shopping" and "Google Product Search" compared to rival services. According to the Commission's statement Google diverts the traffic from rival shopping sites to its own sites and prevents their competitive actions which entails disadvantage for consumers and the other firms (European Commission, 2015e). More specifically, the statement concludes that Google systematically positions its own comparison services in its general result pages not regarding to its merits, since 2008. The System of penalty has not been applied to its own shopping comparison services of which applied to all other sites with the similar aim. As a result of the inquiry it has been found out that Froogle, Google's first comparison shopping site, performed rather poorly since it has not exploited the favorable treatment. In contrast, 
the Google Product Search and Google Shopping displayed a considerable growth compared to rival states since they have benefited from the Google's systematic favoring of them (European Commission, 2015e). Thus, Google's actions have a negative impact on consumers and innovations.

One of the recent cases concerning forming a cartel has been about car battery recycling. The European Commission alleged five leading car battery recycling companies of forming a purchasing cartel (European Commission, 2015f). Unlike the above mentioned cases, the statement of objections does not prejudge the result of the inquiry. All lead -acid based batteries are recycled in Europe. Car batteries make up an important percent of these batteries. The scrap batteries are bought by the recycling companies and the lead is extracted from them. Afterwards, the recycled car batteries are converted from being a waste to resources that can be used in producing new products. The Commission suspects that five leading company in car battery recycling, from 2009 to 2012, formed a cartel targeting to fix purchasing prices for scrap lead-acid batteries in Belgium, Germany, France and the Netherlands (European Commission, 2015f). With the aim of maintaining higher profit margins, according the Commissions state of objections, those companies agreed or coordinated their conduct. These actions prevent reduction in the costs of recycled product which results in higher prices for consumers and less profit for scrap dealers. Thus, such conducts would breach EU anti - cartel rules, basically the article 101 of the TFEU.

The proposed acquisition of TNT by FedEx is an important case regarding EU's merger rules. An in-depth inquiry has been opened by the Commission to evaluate if the proposed acquisition of TNT by FedEx is in line with the EU merger regulation. The companies in this case are global actors in small package delivery sector. The concern of the Commission is based on insufficient competitive pressure coming from only two firms remained in the Global scene, namely UPS and DHL, which would lead to higher prices both for consumers and costumers (European Commission, 2015g). The EU Competition Policy Commissioner Margrethe Vestager stressed the important role of small package delivery system, especially in e-commerce, and Commission's role in ensuring competitiveness in the sector as:

"Many businesses, and in particular e-commerce, rely heavily on affordable and reliable small package delivery services, and many consumers depend on these services to ensure rapid and safe delivery of goods they have bought. The Commission must therefore make sure that FedEx's takeover of TNT would not impede effective competition and would not lead to higher prices for consumers." (European Commission, 2015g)

The companies in question are two out of only for so called "integrators" operating in Europe. Integrators are businesses administers a widespread air and road delivery network within Europe and have the capacity of offering various ways of small package delivery services (European Commission, 2015g). DHL and UPS are the other integrators operating in Europe. The other integrators would be the only considerable rivals, according to preliminary investigation of the Commission, with a destination within or beyond Europe. Thus, the Commission suspects that reduction in the number of the competitors in the sector will result 
in reduction in competition. Moreover, the initial market inquiry of the Commission displayed that the proposed acquisition would create an entity which would have very high market share in servicing some destinations that evokes competition concern of the Commission (European Commission, 2015g). The Commission is assigned to evaluate mergers and acquisitions involving firms with a turnover above certain thresholds and prohibit concentrations which considerably reduce competition in the EU or an important part of it.

\section{Conclusion}

In this study, the EU's impact on global economy through its competition policy has been discussed. The discussion has been intended to be realized via political economy perspective. Thus, the paper began with an assessment of political economy. A contextual observation about scope, implication and aptness to the case of political economy has been made. It has been displayed that competition policy of the EU and its effect are just exact match with the overall assumptions and methods of political economy. Therefore, the study has been pursued to explain European Competition Policy. At this part of the study competition policy and its economic, political, legal and historical rationale has been evaluated. The treaty foundations and legal aspects have been presented and different types and scopes of European Competition Policy have been displayed. Different fields, such as antitrust, state aid, mergers and liberalization that are dealt within the scope of competition policy have been demonstrated. The following chapter has been dealt with the implementation of competition policy. At which conditions would the EU be involved and what kinds of acts would be considered as contrary to competition law has been presented. Furthermore, actions that are considered against fair competition and measures taken to forbid and stop them have been displayed. Finally, several cases which are within the scope of competition policy and carry extraterritorial economic and political concerns and consequences have been revealed. Especially the emphasis dedicated to their relevance with international political economy. Thereby, the evidence, together with theoretical considerations, has been shown that the EU exercises both political and economic influence through its competition policy.

Although the EU is not a typical international actor, as it does not carry the specific sovereignty of a nation state, it bears far more responsibilities compared to other non-state actors based on the Treaties and, thus, developed an international identity. The international identity of the EU in competition has domestic, international and legal grounds, as it has independent competition policy, competition law and ability to sign international agreements with the third parties. The international identity of the EU is predominantly characterized by competition policy as it has a distinctive supranational authority in this field. Of course, as it is the case for all EU common policies, the member states have impact on formulation and implementation of the competition policy, but they also fear that the EU may make decision against their national interests. This fear is usually based on the risk of politicization of the decision making process in competition policy. This usually happens when one or more countries put pressure and make lobbying in the Commission on favor of some member states. This may be also case for non-member states or actors. Thus, in terms competition 
policy, the EU interacts both with internal and external actors and it has the ability for formation and implementation of extra territorial policy, which makes the EU an important political actor in international political economy through its competition policy.

\section{References}

Cini, M., \& McGowan, L. (1998). Competition Policy in the European Union. Basingstoke: Macmillan.

Cohn, T. H. (2012). Global Political Economy. London: Longman.

Damro, C. (2001). Building an International Identity: the EU and Extraterritorial Competition Policy. Journal of European Public Policy, 8(2), 208-226.

De Bièvre, D., \& Eckhardt, J. (2010). The Political Economy of EU Anti-dumping Reform. ECIPE Working Paper Series No. 03/2010., 1-18.

EU. (2003). Council Regulation (EC) No 1/2003 of 16 December 2002 on the implementation of the rules on competition laid down in Articles 81 and 82 of the Treaty. Retrieved 12 12, 2015, from EUR-Lex: http://eur-lex.europa.eu/legalcontent/EN/ALL/?uri=CELEX:32003R0001

European Commission. (2013, 2 27). In the following section more recent cases concerning competition will be displayed in order to analyze the effect of the competition law on real economy. . Retrieved 1 21, 216, from Press Releases: http://europa.eu/rapid/pressrelease_IP-13-167_en.htm

European Commission. (2015a). Microsoft case. Retrieved 1 22, 2015, from Competition: http://ec.europa.eu/competition/sectors/ICT/microsoft/

European Commission. (2015b). Retrieved 1 25, 2016, from European Competition Network: http://ec.europa.eu/competition/ecn/index_en.html

European Commission. (2015c, 12 3). State aid: Commission opens formal investigation into Luxembourg's tax treatment of McDonald's. Retrieved 01 26, 2016, from European Commission - Press release: http://europa.eu/rapid/press-release_IP-15-6221_en.htm

European Commission. (2015d, 04 22). Antitrust: Commission sends Statement of Objections to Gazprom for alleged abuse of dominance on Central and Eastern European gas supply markets. Retrieved 1 25, 2016, from European Commission - Press release: http://europa.eu/rapid/press-release_IP-15-4828_en.htm

European Commission. (2015e, 4 15). Antitrust: Commission sends Statement of Objections to Google on comparison shopping service. Retrieved 1 25, 2016, from European Commission - Fact Sheet: http://europa.eu/rapid/press-release_MEMO-154781_en.htm 
European Commission. (2015f, 07 24). Antitrust: Commission sends statement of objections to suspected participants in car battery recycling cartel. Retrieved 0126,2016 , from European Press Release: http://europa.eu/rapid/press-release_IP-15-5254_en.htm

European Commission. (2015g, 07 31). Mergers: Commission opens in-depth investigation into proposed acquisition of TNT by FedEx. Retrieved 01 26, 26, from European Commission - Press release: http://europa.eu/rapid/press-release_IP-15-5463_en.htm

European Commission Directorate-General for Communication. (2014). The EU explained: Competition. Luxembourg: Publications Office of the European Union.

Gilpin, R. (1987). The political economy of international relations. Princeton: Princeton University Press.

Jones, A., \& Sufrin, B. (2011). EU Competition Law: Text, Cases, and Materials. Oxford: Oxford University Press.

Motta, M. (2004). Competition Policy: Theory and Practice. New York: Cambridge University Press.

Whish, R., \& Bailey, D. (2015). Competition Law. Oxford: Oxford University Press. 